\title{
Voluntarism in occupational health and safety: the New Zealand response
}

\author{
Elizabeth A. Mullen*
}

There has been considerable debate as to whether attempting to improve health and safety practices at work by legislation is more effective than voluntarism and the play of market forces. A survey was conducted in mid 1988 to ascertain the response of New Zealand enterprises to a Voluntary Code of Practice (1987) issued by the Advisory Council for Occupational Safety and Health. An attempt was also made to identify internal and external factors which might have influenced the decision to comply. It would appear that a voluntary approach has some part to play, but the absence of effective health and safety legislation in New Zealand may particularly disadvantage those working in small firms in high risk industries.

\section{Introduction}

Governments in the western world have attempted a number of approaches to encourage or compel managements to improve health and safety standards for their workforces. In the early 1970s, the United States, together with many European nations, tackled occupational health and safety by way of drastic revision of their legislation. Canada, and to some extent Australia, followed suit in the late 1970s. In contrast, New Zealand directed its attention, not to legislative attempts to reduce industrial injury and disease, but to compensation in the form of the Accident Compensation Act 1972. New Zealand has subsequently failed to address the issue of its scattered and often ineffective legislation governing health and safety in the workplace (Duignan, 1983, p.100; Campbell, 1983 , p.92; 1986, p.177; 1987, p.16). Compensation for workers tended to be the number one priority with neither prevention nor rehabilitation given the attention that the originators of the scheme envisaged.

The question of the reform of industrial health and safety legislation resurfaced in 1987 with the promulgation of a voluntary Code of practice for health and safety representatives and health and safety committees. This code was developed out of consultation between the Department of Labour, the New Zealand Employers Federation (NZEF) and the Federation of Labour (now the New Zealand Council of Trade Unions), under the auspices of the Advisory Council for Occupational Safety and Health (ACOSH). The ACOSH code of practice was issued in 1987 by the Department of Labour to all registered factories in New Zealand, employing more than 10 people. Codes of practice have been issued previously to various sectors of industry, but this new code represented a novel attempt to standardise practices throughout New Zealand enterprises. The ACOSH code provided for the: "election, functions, rights and obligations of employee health and safety representatives and the establishment, membership, functions and procedures of joint employer/employee health and safety committees" (Department of Labour, 1987, p.3).

Department of Management, University of Otago. Special thanks to my supervisor, Ian McAndrew and to Valerie Thompson for her technical assistance. 
The code identified an active role for employee representatives with regard to the right to information, the right to make representations to employers, time off for attendance at trade union health and safety training courses, the right to refuse dangerous work, accompanying inspectors and receiving their reports to the company and inviting in technical advisers from appropriate outside organisations, including trade unions.

The New Zealand Employers Federation, despite its direct involvement in the development of the ACOSH Code, simultaneously issued an alternative code of practice (NZEF, 1987). This NZEF code modified some key provisions of the ACOSH code, particularly some of the elements concerned with the role of representatives, and the direct involvement of trade unions.

A number of influences on health and safety practices, and by implication on the adoption of a code of practice, have been reported in recent years. In the United Kingdom, it has been found that managements which accord personnel matters a relatively high priority in decision making are more disposed toward the introduction of safety representative regulations (Beaumont and Leopold, 1982, pp.73-4). Several New Zealand studies have identified the importance of the hierarchical level of, and the amount of time spent by the person responsible for health and safety, the involvement of trade unions and the inclusion of appropriate clauses in negotiated awards and agreements (Chew, 1984, p.566; Duignan, 1983, p.104; McIntosh and Gurdon, 1986, p.529; Campbell, 1987, p.40).

Studies in New Zealand and overseas have confirmed that government rules and inspection and the provision of training for those with specific responsibility for health and safety are essential ingredients in the reduction of accidents and ill health (McIntosh and Gurdon, 1986, p.531; Parmeggiani, 1982, p.282; Campbell, 1983, p.95). Stress has also been placed on the need for clear definition of the rights of workers with regard to access to information on workplace hazards and participation in the health and safety decision making processes (Kjellstrom, 1983, pp.107-8; Parmeggiani, 1982, p.275; Campbell, 1983, p.94; 1986, p.178).

It has been suggested that foreign ownership and control of an organisation may lead to improved management of personnel and industrial relations matters and hence contribute to the effectiveness of enterprise health and safety programmes (Campbell and Rowan, 1983, p.31; McIntosh and Gurdon, 1986, p.522; Purcell, Marginson and Sisson, 1987, p.134). McIntosh and Gurdon concluded from their study that in New Zealand multinational (foreign owned) enterprises instituted significantly more effective health and safety programmes than domestic enterprises. They saw this as arising from the greater skills demonstrated by multinationals in industrial relations and their willingness to accord trade unions a legitimate role in health and safety decisions. For example, multinational enterprises in McIntosh and Gurdon's study were far more likely to have negotiated health and safety clauses into awards and agreements.

The rate of adoption of a voluntary code of practice (ACOSH or NZEF) in New Zealand enterprises was included as part of a much broader project looking at the presence and scope of health and safety programmes in New Zealand enterprises and how this was influenced by enterprise size, a degree of foreign ownership, managerial practices, risk levels, inspection, and trade unions.

\section{Method}

\section{Subjects}

A random sample of all economically active organisations in New Zealand was selected from the New Zealand Business Directory (1988), held on computer by the Department of Statistics. The sample was stratified according to the New Zealand 
Standard Industrial Classification (NZSIC) to ensure the selection of the full range of enterprise types and productive activities with their associated levels of industrial risk.

As the ACOSH Code of Practice was only sent to firms employing 10 or more people, all firms employing less than 10 were excluded. Despite this exclusion there was still a danger of swamping the sample with the large number of small organisations in New Zealand. The sample was therefore disproportionately selected on the basis of 10-49 employees 1:100, 50-99 employees 1:50 and 100+employees 1:10. These ratios were varied within several of the NZSICs where the total number of enterprises was too low to ensure selection of all size categories. The initial sample size was 415.

Demographic data, which included the number of business locations, number of persons employed, the New Zealand Enterprise Industrial Classification (NZEIC), business type and degree of foreign ownership was supplied from the Directory for each enterprise.

\section{Design}

The hypothesis for this study was that the size of the enterprise, degree of foreign ownership and scope of enterprise health and safety practices would have an effect on the adoption rate of a code of practice. The influence of these factors would be moderated by the activities of trade unions, the level of industry risk and the level of inspection.

\section{Independent variables}

Enterprise size and degree of foreign ownership was obtained as part of the data base from the New Zealand Business Directory. The scope of health and safety practices within the enterprise was operationalised under 4 categories:

(i) Responsibility: this related principally to the role and seniority of the person with overall responsibility and the amount of time that person spent on health and safety matters;

(ii) Policy and procedures: this covered the existence of company health and safety policy, written health and safety rules, the presence of health and safety responsibilities in individual job descriptions and the inclusion of health and safety procedures in induction programmes;

(iii) Training: the provision of training for the person with specific responsibility for health and safety and for employees at the various levels within the organisation;

(iv) Negotiated clauses in awards and agreements.

\section{Moderating Variables}

Risk was operationalised by the enterprise ACC levy per $\$ 100$ of payroll and the enterprise rating of the level of risk entailed in its productive activities. Inspection was operationalised by the level of inspection during the previous twelve months.

The trade union variable was operationalised in 3 parts:

(i) Trade union general influence was concerned with trade union ability to negotiate clauses into awards and agreements, to resist pressure for enterprise bargaining during the 1987/88 wage round and by confirmation by the enterprise that trade unions had been influential in their health and safety programmes; 
Trade union direct influence on health and safety decisions within the enterprise with regard to participatory schemes and the adoption of a code of practice;

(iii) Trade union size was based on the size of the main trade union representing the workforce in an enterprise.

\section{Instrumentation}

A 16 page questionnaire was developed principally on the basis of previous studies reported by Beaumont and Leopold (1982) and McIntosh and Gurdon (1986).

A small pilot study with a sample of 10 local enterprises selected from the $N e w$ Zealand business who's who (1987) was conducted to test face, content and construct validity. Following a 100 percent response, some sections of the questionnaire were reformatted, extended or omitted.

\section{Postal procedure}

The postal survey procedure suggested by Hoinville, Howell and Associates (1979, p.60) was used. Questionnaires were mailed to the 415 enterprises in the sample with a covering letter and prepaid return envelope. After 3 weeks, 125 completed questionnaires had been received. A reminder was sent out in the fourth week and a further 38 responses were received. A second reminder elicited 89 responses giving a total of 252 responses.

\section{Variable weighting}

Responses to individual questions under relevant questionnaire sections relating to the operationalised variables were grouped by way of a weighted score derived on the basis of an assessment of the relative importance of the individual factors. This score was transformed into a percentage. To facilitate analysis using cross-tabulations and chisquares, these percentage scores were placed in interval scales. Statistical analysis was undertaken using the Statistical Package for the Social Sciences (SPSS-X). To eliminate bias due to disproportionate sampling, all results were weighted back to reconstruct the characteristics of the original population.

\section{Results}

\section{Sample characteristics}

Of the initial sample of 415 enterprises, 30 (7.2 percent) were unusable as they could not be traced, had ceased to trade or had fallen below 10 employees. This left a usable sample of 385 . A response rate of 66 percent was obtained which generated a data base of 252 valid responses.

The sample consisted of 222 (88.2 percent) domestic New Zealand enterprises, 5 (1.8 percent) had minority foreign ownership and 25 (10.0 percent) majority foreign ownership. (Population 85.0 percent, 2.0 percent and 13 percent respectively).

The sample frequencies in the three size groups were, $10-49$ people 79.6 percent, 50 99 people 10.2 percent and $100+$ people 10.0 percent (population 80.5 percent, 10.2 percent and 9.5 percent respectively). The average levy for the enterprises in the study 
was $\$ 2.60$ per $\$ 100$ of payroll (the average reported by New Zealand Law Commission for $1987 / 88$ was $\$ 2.65$ per $\$ 100$ of payroll). The average number of persons engaged by an enterprise was 64.8 at 3.4 business locations. (Population 71.9 at 1.6 locations).

Demographic data for the early and late responders was compared to that of nonresponders and unusables. There was no difference between early and late responders. Non-responding and unusable enterprises were smaller, employing on average 51 people at 2.5 business locations. The average levy for this group per $\$ 100$ of payroll was \$1.40. Data for populations was taken from New Zealand business patterns (Department of Statistics, 1987).

\section{Adoption of a voluntary code of practice}

The ACOSH code was received by 40.0 percent of the sample while 32.2 percent reported receiving a copy of the NZEF code. Adoption of the ACOSH code was considered by 19.4 percent of the sample and 16.2 percent considered the NZEF code. Adoption of a code was reported by 14.6 percent of the respondents.

An entire code was adopted by 2.5 percent for the ACOSH code and 2.1 percent for the NZEF code. A modified version (which for some enterprises involved some combination of the two codes) was selected by 9.7 percent for the ACOSH code and 5.9 percent for the NZEF code. The frequencies for the key stages of the adoption process are set out in Table 1.

Table 1: Code of practice adoption process (percentage)

ACOSH Code

NZEF Code

\begin{tabular}{lcccccc}
\hline & Yes & No & $\begin{array}{c}\text { Don't } \\
\text { Know }\end{array}$ & Yes & No & $\begin{array}{c}\text { Don't } \\
\text { Know }\end{array}$ \\
& 40.0 & 32.9 & 25.4 & 31.5 & 40.5 & 25.9 \\
Received a copy & 19.4 & 12.6 & 9.6 & 16.2 & 12.3 & 8.9 \\
Considered adoption & 2.5 & - & - & 2.1 & - & - \\
Adopted entire code & 9.7 & - & - & 5.9 & & - \\
Adopted modified version & & & & & & \\
\hline
\end{tabular}

\section{Trade unions and voluntary codes of practice}

The frequencies for direct influence of trade unions on worker participation in health and safety within the enterprise and adoption of a code of practice were low. Each enterprise was assigned a percentage score. No enterprise scored above 50 percent and most ( 94 percent) scored zero. Despite this finding, a code of practice was adopted by 2.3 percent of respondents as the result of a request to include a code in a 1987/88 award or agreement, and 1.6 percent had adopted a code as the result of a direct request from the trade union(s) representing their workforce. 
The correlations between the rate of adoption of a code of practice and trade union general influence, trade union size and trade union influence on worker participation and adoption of a code of practice were all significant $(r=.29, p<.0001, r=.22, p<.0001$ and $r=.44, p<.0001$ respectively). When partial correlations were conducted for these variables, controlling for size of the enterprise, the correlation for the general influence of trade unions weakened but the correlation with the influence on worker participation and codes of practice did not change.

The trade union influence on worker participation and adoption of a code of practice variable accounted for 25 percent of the variance in the adoption of a code of practice in step 1. of stepwise multiple regression. Enterprise policy and level of responsibility accounted for a further 9 percent of the variance (sce Table 2).

Table 2: Stepwise multiple regression with the adoption of a code of practice as dependent variable

Independent Variable

r-squared

Beta

Step 1: Trade union influence on worker participation and codes of practice

Step 2: Policy

Correlations on the variables which appeared in stepwise multiple regression (shown in Table 2) and trade union general influence were all significant. Very low levels of correlation were obtained for these variables with trade union size, but again, these were significant (see Table 3).

No significant correlation was found between enterprise size and trade union general influence. There was a significant but low correlation between enterprise size and trade union size $(r=.22, p<.0001)$.

Table 3: Pearson's $r$ for trade union variables and explanatory variables in stepwise multiple regression

Trade union general influence Trade union size

Trade union influence on worker participation and codes of practice

$.25 \mathrm{p}<.0001$

$.15 \mathrm{p}<.008$

Policy

$.30 \mathrm{p}<.0001$

$.17 \mathrm{p}<.004$

Responsibility

$.22 p<.0001$

$.16 p<.006$ 


\section{Scope of health and safety practices}

The correlation between the adoption rate of a code of practice and health and safety policy and procedures within the enterprise was $r=.44, p<.0001$. The correlation with responsibility, which related to the hierarchical level of the person(s) responsible and time spent on health and safety matters was $\mathrm{r}=.38, \mathrm{p}<.0001$. To ensure that enterprise size was not confounding these results, partial correlation controlling for size was conducted. Correlations between policy and responsibility and the code of practice variable fell to $\mathrm{r}=.41, \mathrm{p}<.0001$ and $\mathrm{r}=.30, \mathrm{p}<.0001$ respectively.

Specific training for the person(s) responsible for health and safety and for employees through the hierarchical levels correlated at $r=.37, p<.0001$ with the rate of adoption. Health and safety clauses had been negotiated into all awards and agreements applicable to the workforce for 48.0 percent of the respondents and 12.1 percent reported that some awards or agreements contained such clauses. The correlations for the variables policy and procedures, and training with clauses in awards and agreements were significant but low $(\mathrm{r}=.23, \mathrm{p}<.0001$ and $\mathrm{r}=.25, \mathrm{p}<.0001$ respectively). Correlations with clauses in awards and agreements with responsibility, and with trade union direct influence in enterprise worker participation and codes of practice were not significant.

\section{Enterprise size and degree of foreign ownership}

The correlation between enterprise size and the adoption of a code of practice was significant $(r=.30, p<.0001)$. However, the expected relationship between a degree of foreign ownership and the rate of adoption of a code of practice could not be demonstrated. Size of the enterprise and degree of foreign ownership did not explain any of the variance in the code of practice variable in stepwise multiple regression.

Of the the variables which influenced the adoption rate of a code of practice in stepwise multiple regression, the level of responsibility taken for health and safety in the enterprise had the highest correlation at $r=.38, p<.0001$ (see Table 4).

Table 4: Correlation of variables in stepwise multiple regression with size of the enterprise

Variables in-stepwise

Pearson's r

multiple regression

with enterprise size

Trade union influence on worker

participation and a code of practice

$$
\mathrm{r}=.21(\mathrm{p}<.0001)
$$

Policy

$\mathrm{r}=.19(\mathrm{p}<.001)$

Responsibility

$$
\mathrm{r}=.38(\mathrm{p}<.0001)
$$

Again, the expected relationship between degree of foreign ownership and organisational practices did not emerge. The correlation between the degree of foreign 
ownership and policy was was very low at $\mathrm{r}=.14, \mathrm{p}<.01$. No correlation was found between degree of foreign ownership and the other two variables shown in Table 4.

\section{The influence of risk}

The only risk variable which correlated significantly with the adoption of a code of practice was inspection $(r=.22, p<.0001)$. The enterprise rating of perceived risk and inspection variables had correlations of $\mathrm{r}=.25, \mathrm{p}<.0001$ and $\mathrm{r}=.21, \mathrm{p}<.0001$ respectively with policy. These results indicate that there was only a small relationship between the identification of risk and action to alleviate such risk. There was no direct evidence that the size of the enterprise or a degree of foreign ownership led to a greater propensity to identify and act on risk. The size of the enterprise did correlate significantly with the responsibility and and policy variables, but the indications were that this was not related to possible risk involved in productive activities.

\section{Impact of a code on participatory schemes}

Some enterprises had set up participatory schemes independently of, and prior to the issuing of the codes of practice. Overall, employee health and safety representatives were reported by 15.6 percent of the respondents and 15.8 percent reported health and safety committees (see Table 5).

Table 5: Frequencies for employee health and safety representatives and committees by size of enterprise

\section{Percentage of sample}

Representatives

Committees

\section{6}

15.8
Number of employees (percentage)

$10-49 \quad 50-99 \quad 100+$

These results were modified when the distribution of participatory schemes across all business locations was examined. Representatives at all locations were reported by 14.1 percent ( 90 percent of those who had representatives) while only 6.2 percent of those who had committees ( 39 percent) had them at all locations. Both committees and representatives were reported by 5.5 percent of the sample and 4.2 percent had an unspecified type of participatory scheme at all locations (see Table 6). 
Table 6: Frequencies for worker participation at business locations (percentage)
All
Some

\section{Representatives}

Committees

Both

Other
14.1

6.2

5.5

4.2

\section{8}

5.8

3.4

3.7

\section{Discussion}

Even by the most generous calculations, of those enterprises which claimed to have received a code of practice, less than 31 percent were prepared to adopt on a purely voluntary basis. Even this figure gives a false picture as, of those who adopted, only a very small proportion were prepared to institute all the provisions of one or other of the codes. Most enterprises adopted in a form which departed significantly from the central provisions of the ACOSH code in particular. This confirms the conclusions drawn by the Department of Labour from their survey (Moir, 1989, p.21) that the impact of voluntary codes on health and safety management was disappointingly slight.

Several key issues arise out of this study which could have major implications for the introduction of effective health and safety regulations. The first is that a factor in the effective management of occupational health and safety, and willingness to comply with regulatory requirements was the enterprise size, the hierarchical level of the people responsible for enterprise health and safety and the amount of time spent on health and safety. There was a definite, if not strong, increased propensity to adopt a voluntary code of practice in larger organisations which recognised the necessity for setting up managerial structures and developing specific procedures for dealing with risk. This confirms the findings in previous studies, that larger enterprises are more likely to comply with legislative requirements and to have someone with specific responsibilities for health and safety at a higher level than smaller enterprises (Beaumont and Leopold, 1982; McIntosh and Gurdon, 1986; Walters, 1987).

Foreign ownership did not emerge as influencing either enterprise health and safety practices or the adoption of a code of practice. This is contrary to previous findings. One large enterprise in this study, which could be readily identified as belonging to an international group, was not classified by the New Zealand business directory (1988) as being foreign owned (being listed as a private limited liability company, business type 2 ), and was not shown as a subsidiary of a multinational or foreign owned company in the New Zealand business who's who (1987). There may have been other enterprises in the sample with similar characteristics which were less easy to identify. This, coupled with the fact that the randomly drawn sample contained 20 percent fewer enterprises with some foreign ownership than the population may account in part for the failure to separate increased performance due to multinational connections from increased performance due to size.

The issue of size raises one of the most difficult problems involved in the move towards improving health and safety in every enterprise for all workers, namely how to target the small firm. In New Zealand, 28 percent of the workforce is employed in firms 
employing less than 10 people. For example, the average number of employees in firms in the Building and Construction Industry is 5.5. Other industries characterised by high levels of risk and small firms include Agriculture, Hunting and Fishing, Mining and Quarrying, and Transport.

The difficulties of improving health and safety practices in these industries could well be exacerbated as changes in employment and operating practices fragment the workforce and loosen traditional affiliations with worker organisations. It is worthwhile at this point to look at a couple of examples from overseas to illustrate the effect that these factors can have on the effectiveness of health and safety legislation.

In the construction industry in the United Kingdom the practice of sub-contracting (sometimes up to 200 small firms on one site) has, according to some authors, led to a loss of control over safety standards by the main contractors and a dramatic increase in the percentage of fatalities and major injuries (Beaumont and Leopold, 1982, p.69; The Economist, 14 November, 1987). Small firms by-pass or ignore statutory requirements in order to remain competitive. Workers remain silent in order to remain in employment. Trade unions are unwilling or unable to intervene, and, in site bargaining, frequently condone the acceptance of unsafe conditions (Codrington and Henley, 1981, p.308).

Walters (1987 p.48), in his study of trade union workplace organisation with regard to health and safety in the printing industry in the UK, suggests that the power and presence of trade unions in the workplace has been eroded as the result of a political philosophy and policy aimed at 'improving' industrial relations. This has minimised the impact of health and safety legislation where trade union workplace power was intended to support and strengthen its effectiveness.

This discussion with regard to the issue of enterprise size and trade unions leads us to the second key factor in this study, the role of trade unions in the adoption and implementation of codes of practice. There was little evidence that trade unions were influential in the selection of representatives or the establishment of health and safety committees for participatory health and safety schemes within the enterprise. They were, however, able to influence the decision to adopt a code of practice in 27 percent of the enterprises which did so. This may have been partly due to the efforts made by the trade unions to encourage the adoption of codes of practice via the health and safety centres set up in the five main centres with ACC funding. The trade unions have also played an essential role in ensuring that a major proportion of even the smallest firms were at least covered by health and safety clauses, however minimal, in awards and agreements.

The incidence of clauses in negotiated awards and agreements was higher in this study than previously reported in New Zealand (McIntosh and Gurdon, 1986, p.529). Over 60 percent of the respondents reported that all or part of their workforce were covered by such clauses. In a recent study to identify managerial bargaining scope in New Zealand, it was found that over 65 percent of employers would be willing to negotiate over health and safety issues at national or enterprise level (McAndrew, 1989, p.145). This could well be related to a wish on the part of employers to pre-empt or avoid the introduction of legislation, but could also reflect past experience that bargaining over such issues has never threatened managerial prerogatives and required little in the way of action. Certainly in this study little relationship could be found between the presence of negotiated health and safety clauses in awards and agreements and an improvement in health and safety practices.

Previous work in this area has led to the suggestion that larger, and therefore potentially more powerful trade unions could be more successful in influencing enterprise health and safety practices (Beaumont and Leopold, 1982, p.72). In this study the general influence of trade unions was not modified by trade union size or restricted to larger enterprises. There was some evidence that larger enterprises were more likely to be covered by a larger trade union although the anticipated relationship between trade union size, enterprise size and the general influence of trade unions did not emerge. Trade 
unions were, for example, able to negotiate clauses into awards and agreements covering enterprises across all size ranges. There is a good case for suggesting that the lack of a clear relationship between trade union strength and plant size in this study could be due to the New Zealand system of nationally negotiated awards and blanket coverage of all firms in the same industry.

The move towards regional, enterprise and even plant level bargaining in New Zealand, now strengthened by the amendment to the Labour Relations Act 1987 allowing employers to cite themselves out of national awards after balloting their workers, will obviously lead to a diminution in blanket coverage. This, coupled with continuing economic problems and high levels of unemployment will lead to a reduction of trade union influence, particularly in smaller enterprises. Firms employing less than 50 people cannot cite themselves out of awards, but the general trend is bound to lead to a reduction in the ability of trade unions to influence organisational obligations with regard to occupational health and safety, whether contractual or statutory, in smaller firms.

The third, and probably the most controversial area, is inspection. The level of inspection experienced by an enterprise in the 12 months prior to the survey appeared to have a small degree of influence on the adoption of a code of practice. No other relationship between risk and inspection and the scope of health and safety practices was found.

The only raison d'être for an inspectorate is that it targets "at risk" firms and is willing and able to take effective action to ensure the introduction and maintenance of statutory safety standards in all enterprises, since "such standards are obviously not worth much if they are not enforced" (Kjellstrom, 1983, p.111). The experience in the United States, for example, is that workers' representatives have complained that enforcement agencies tend to be more attentive to employers' economic considerations than the health and safety of workers. In the United Kingdom, sanctions have not been applied to cases of failure to observe regulations due to the reluctance of agencies to press charges (Campbell, 1986, pp.178 and 183).

Despite the average ACC levy for the sample being close to the population average, and the fact that these are based on the individual assessment of risk for enterprise productive activities, there was no indication that the level of risk associated with ACC levies alerted enterprises to the potential risk entailed in their operations. This could be more than partly due to the general feeling that levies are unfairly high and therefore do not reflect actual risk. In the United Kingdom Leopold and Beaumont (1983, p.136) found that identification of risk was associated with a greater propensity to comply with statutory requirements to set up participatory structures. No such association was found in this study.

There have obviously been difficulties in the past in coordinating the work of the various agencies responsible for the maintenance of health and safety standards in New Zealand. This could be facilitated by bringing the institutions which deal with occupational health and safety together under one umbrella with a universally applied set of standards and access to all available data. Identification of 'at risk' firms should not present a problem, as the ACC has records of the worst performers. The inspectorate, as a matter of urgency, should have access to these records as a first step towards improving their performance. It will certainly take time to establish structures and procedures which will ensure long term security, but regular and accurate inspection, coupled with the ability to take appropriate action can modify the worst practices (The Economist, 14 November, 1987).

The final area for consideration is worker participation in workplace health and safety decision making. The results of this study and the survey undertaken by the Department of Labour suggest that there was only a limited willingness to comply with the participatory structures which formed the basis of the ACOSH code. To some degree this appears to be a function of size. Of the enterprises in this study employing more than 50 people, 42 percent had health and safety committees and 38 percent had health 
and safety worker representatives. The Department of Labour selected its survey sample on a different basis from this study (with no category for firms employing less than 50 people). This complicated comparison between the 2 surveys.

However, they reported that 43 percent of their sample had health and safety committees and 32 percent had worker representatives (very similar study for enterprises employing more than 50 people). It was the enterprises in the group employing between 10 and 49 people where little progress had been made. Only 9 percent had committees and 10 percent had worker representatives. While the figures presented above do not appear to be too damning, particularly for larger enterprises, the Department of Labour survey also found that only 30 percent of the firms in their study had equal management/supervisor/employee representation. The vast majority had no employee representatives at all. Overall, the findings of both surveys would appear to confirm the contention that New Zealand employers are unenthusiastic about worker participation, particularly when there is a clear role for trade unions and an equal say for workers (Campbell, 1987, p.101; Committee of Enquiry into Industrial Democracy, 1989, p.7; New Zealand Business Round Table, 1989, p.19).

\section{Conclusion}

There can be little doubt that the attempt to tackle occupational health and safety by voluntary means has only had very limited success in New Zealand. The actual rate of adoption of a code of practice was cause for concern, but even more worrying was the fact that adoption was only minimally associated with industry risk. Compliance, whether voluntary or in response to legislation, is meaningless where it cannot be shown to have a direct impact on the reduction of accidents and ill health in high risk industries.

In June 1988 ACOSH issued a public discussion paper, entitled Occupational safety and health reform, which put forward a one act, one authority framework for legislation. The basic principles included a role for the Government, employers, and workers and their representatives. What is difficult to understand is why the Discussion Paper was so hastily issued, prior to the completion of the Department of Labour's survey on the response to the voluntary code of practice, and was not followed up with the introduction of a Bill until July 1990.

Experience elsewhere suggests that legislation cannot replace health and safety programmes, but it can encourage their development (Singleton, 1983, p.167). There is also general agreement that legislation should make provisions for truly participatory structures within the enterprise, a legitimate role for trade unions and an effective inspectorate with a mandate to take whatever action is necessary, up to and including plant closure (Parmeggiani, 1982, p.275; Kjellstrom, 1983, p.107; Campbell, 1987, pp.41-2; The Economist, 14 November, 1987).

It remains to be seen whether the new legislation will be passed and if so, whether it will ensure the provision of acceptable minimum safety standards for all workers. The indications are that this legislation will not carry a mandatory requirement for enterprises to set up participatory structures, nor will there be a clearly defined role for trade unions. The failure to include these elements can only be seen as a retrograde step, below what workers and their representatives could have expected based on the provisions of the ACOSH code of practice. The proposals are, however, very much in line with the view of New Zealand employers that compulsion is not conducive to cooperation and could be counter-productive in the development of relationships between employer and employee to facilitate improved performance in occupational health and safety via, for example, education and training programmes. It is unlikely that employers who were recalcitrant in complying with a voluntary code of practice will suddenly undertake cooperative 
arrangements with their workers and provide education, training and other programmes which will increase their health and safety performance.

In addition to the failure to introduce some mandatory element for participatory structures, the less detailed, performance standard, general duty nature of the proposed legislation (partly to facilitate flexibility in dealing with technological and other change) moves away from the specific standards and regulations which formerly applied. This has the potential for lightening the load of recalcitrant employers even further. The problems that this sort of legislation can create is documented by Parmeggiani (1982, p.273) who suggests that:

The type of legislation is important from an enforcement point of view, the less detailed the greater the technical skill required from the inspectorate. Legislation which just states objectives puts a burden on medium and small enterprises ...

Legislation does seem to be the next logical step. The expectation was that this would be formulated on the basis of the Code of practice for health and safety representatives and health and safety committees (1987), or at least on the less radical public discussion paper Occupational safety and health reform (1988). It remains to be seen whether the Government's actual legislative response, which makes fewer demands on employers, has potential for greater demands on the inspectorate and gives no statutory right for workers and their representatives to be involved, is sufficient for real progress to be made in improving New Zealand's occupational health and safety record. The chances are that real improvement may be just as, or even more, remote than it was before.

\section{References}

Advisory Council for Occupational Safety and Health (1988) Occupational safety and health reform: a public discussion paper. Wellington, ACOSH.

Beaumont, P. B. and Leopold, J. W. (1982) A failure in voluntarism: the case of joint health and safety committees in Britain. New Zealand journal of industrial relations. $7(2): 61-75$.

Campbell, I. B. (1983) New Zealand occupational health and safety legislation viewed against the world scene. New Zealand journal of industrial relations. 8(2): 87-96.

Campbell, I. B. (1986) Occupational health and safety legislation: possibilities for future development. New Zealand journal of industrial relations. 11(3): 177-189.

Campbell, I. B. (1987) Legislating for workplace hazards in New Zealand: overseas experience and our present and future needs. Palmerston North, Massey University.

Campbell, D. C. and Rowan, R. L. (1983) Multinational enterprises and the OECD industrial relations guidelines. University of Pennsylvania, Industrial Research Unit.

Chew, C. K. (1984) Lost time work accidents in an industry. The New Zealand medical journal. (August): 564-567.

Cook, W. N. and Gautschi, F. H. (1981) OSHA, plant safety programmes, and injury reduction. Industrial relations. 20(3): 245-257. 
Codrington, C. and Henley, J. S. (1981) The industrial relations of injury and death: safety representatives in the construction industry. British journal of industrial relations. 19(3): 297-315.

Committee of Inquiry into Industrial Democracy (1989) Report. Wellington.

Department of Labour (1987) Code of Practice for health and safety representatives and health and safety committees. Wellington.

Department of Statistics (1987) New Zealand business patterns. Wellington, Department of Statistics.

Duignan, P. (1983) Occupational health and safety in New Zealand: problems and solutions. New Zealand journal of industrial relations. 8(2): 99-105.

Gevers, J. K. M. (1983) Worker participation in health and safety in the EEC: the role of representative institutions. International labour review. 122(4): 411-428.

Hoinville, G., Jowell, R., and Associates (1978) Survey research practice. Heinemann Educational Books Ltd.

Kjellstrom, T. (1983) Some crucial issues concerning safety provided by occupational health standards. New Zealand journal of industrial relations. 8(2): 107-112.

Leopold, J. W. and Beaumont, P. B. (1983) Health and safety and industrial relations: a UK study. New Zealand journal of industrial relations. 8(2): 135-145.

McAndrew, I. (1989) Bargaining structure and bargaining scope in New Zealand: the climate of employer opinion. New Zealand journal of industrial relations. 14(2): 133148.

McIntosh, B. and Gurdon, M. A. (1986) Factors influencing health and safety performance in New Zealand. The journal of industrial relations. 28(4): 521-533.

Moir, R. (1989) Safety reps code not well known. Journal of occupational safety and health (Safeguard). 2: 20.

New Zealand Business Round Table (1989) Industrial democracy: a case for regulation or deregulation. Submission to the Committee of Enquiry into Industrial Democracy. Unpublished.

New Zealand business who's who (1987) (28th Edition). Fourth Estate Holdings Ltd.

New Zealand Employers Federation (1987) Code of practice for health and safety representatives and health and safety committees. Unpublished.

New Zealand Law Commission (1988) Personal injury: prevention and recovery. (Report No.4) Wellington.

Parmeggiani, L. (1982) State of the art: recent legislation on workers health and safety. International labour review. 121(3): 271-285. 
Purcell, J., Marginson, P., Edwards, P. and Sisson, K. (1987) The industrial relations practices of multi-plant foreign owned firms. Industrial relations journal. 18(2): 130137.

Singleton, W. T. (1983) Occupational health and safety systems: a three country comparison. International labour review. 122(2): 155-168.

Walters, D. (1987) Health and safety and trade union workplace organisation - a case study in the printing industry. Industrial relations journal. 18(1): 40-49. 